\title{
Deoxyribonucleic Acid Hybridization Studies Among Some Strains of Group D and Group N Streptococci
}

\author{
DENNIS R. ROOP, J. ORVIN MUNDT, and W. STUART RIGGSBY \\ Departments of Microbiology and of Food Science and Technology, \\ University of Tennessee, Knoxville, Tennessee 37916
}

\begin{abstract}
The degree of homology between group D (Streptococcus faecalis and $S$. faecium) and group $\mathrm{N}$ (S. lactis) streptococci was assessed by deoxyribonucleic acid (DNA)-DNA hybridization. Interspecific DNA duplexes between $S$. faecalis and $S$. faecium exhibited high levels $(>75 \%)$ of formation at 60 and $70 \mathrm{C}$, and low levels $(<10 \%)$ of DNA duplex formation were observed between group D and group $\mathrm{N}$ organisms at 60 and $70 \mathrm{C}$. Thermal stability studies indicated less than $2 \%$ unpaired bases in these duplexes. Atypical strains which have characteristics of both group D and group N streptococci were included in an attempt to identify them with established species. The results indicate that DNA-DNA hybridization studies may be useful in placing atypical strains in a particular species if screening of physiologic properties is used to separate these strains into groups resembling $S$. faecalis, $S$. faecium, and $S$. lactis. Results obtained with an authentic strain of $S$. faecium subsp. casseliflavus Mundt and Graham indicate that this organism deserves the subspecific designation.
\end{abstract}

There are numerous reports of the isolation of atypical enterococci from diverse animal and plant sources $(10,17,24,26)$. These strains possess sets of characteristics that prevent their placement in established taxa. Raj and Colwell (26) subjected streptococci to a variety of tests and analyzed the data by computer; they suggested that certain unclassified strains of enterococci deserve recognition as a distinct taxonomic entity at the species level. Colobert and Blondeau (10) proposed the name Streptococcus innominatus for the unclassified enterococci.

The isolation of streptococci from plants has produced a large collection of atypical strains. These strains exhibit characteristics of both group D (S. faecalis and $S$. faecium) and group $\mathrm{N}$ (S. lactis) streptococci. Since all previous attempts to classify these strains among well established species were based on comparison of the phenotypic expression of small parts of the genomes, it was of interest to compare the entire genomes of these organisms with those of known reference strains by the use of deoxyribonucleic acid (DNA)-DNA hybridization determinations.

It was first necessary to determine whether $S$. faecalis, $S$. faecium, and $S$. lactis could be differentiated by means of DNA-DNA hybridization. On the basis of the physiologic properties of group D and group $\mathrm{N}$ streptococci
(Table 1) and of previous results of DNAribonucleic acid hybridization studies by Miller and Morgan (23), it seemed probable that differentiation between these groups could be made with this method. However, it was not certain that a distinction could be made between $S$. faecalis and $S$. faecium.

Recently, Mundt and Graham (24) proposed the recognition of $S$. faecium subsp. casseliflavus as a taxon of streptococci associated with plants. These yellow-pigmented streptococci constitute a homogeneous group with properties of both $S$. faecalis and $S$. faecium, but their physiology, ecology, and motility set them apart from these species (24). Since then, Taylor et al. (27) have questioned the use of pigmentation as a single characteristic for establishing this subspecies. They suggest that pigmentation, unlike the single characteristics identifying $S$. faecalis subsp. liquefaciens and $S$. faecalis subsp. zymogenes, is of doubtful value as a basis for making this designation. As stated above, the proposed recognition of $S$. faecium subsp. casseliflavus was not based solely on pigmentation. ATCC 25788 , an authentic strain of $S$. faecium subsp. casseliflavus, was included in this study to examine its relatedness to the reference strains employed.

(This paper is taken in part from a thesis submitted by D. R. R. to the Graduate School, University of Tennessee, in partial fulfillment 
of the requirements for the M.Sc. degree.)

\section{MATERIALS AND METHODS}

Bacterial strains. The strains used in this study are listed in Table 2. Escherichia coli $\mathrm{K}-12$ was used as a control in median thermal dissociation temperature $\left(T_{m}\right)$ determinations.

Media. Strains of $S$. faecalis and $S$. faecium were

TABLE 1. Physiologic characteristics of group $D$ and group $N$ streptococci

\begin{tabular}{|c|c|c|c|}
\hline Characteristic & $\begin{array}{l}\text { S. fae- } \\
\text { calis }\end{array}$ & $\begin{array}{c}\text { S. fae } \\
\text { cium }\end{array}$ & $\begin{array}{l}\text { S. lac- } \\
\quad \text { tis }\end{array}$ \\
\hline \multirow{2}{*}{\multicolumn{4}{|c|}{$\begin{array}{l}\text { Growth at } 10 \text { and } \\
45 \mathrm{C}\end{array}$}} \\
\hline & + & + & - \\
\hline \multicolumn{4}{|l|}{ Growth in $6.5 \%$} \\
\hline $\mathrm{NaCl}$ & + & + & - \\
\hline Growth at $\mathrm{pH} 9.6$ & + & + & - \\
\hline \multicolumn{4}{|l|}{ Growth on tellu- } \\
\hline \multirow{2}{*}{\multicolumn{4}{|c|}{$\begin{array}{l}\text { Growth on bile es- } \\
\operatorname{culin}^{a}\end{array}$}} \\
\hline & + & + & - \\
\hline Reduction of TTC & + & - & - \\
\hline \multicolumn{4}{|l|}{ Fermentation of: } \\
\hline melibiose & - & + & - \\
\hline melezitose & + & - & - \\
\hline sorbitol & + & - & - \\
\hline raffinose & - & + & - \\
\hline
\end{tabular}

${ }^{a}$ Taken from Facklum and Moody (15); all other data are from Mundt and Johnson (25). grown in a medium consisting of tryptone $(1 \%)$, yeast extract $(0.5 \%)$, glucose $(1 \%), \mathrm{NaCl}(0.5 \%)$, and $\mathrm{K}_{2} \mathrm{HPO}_{4}(0.5 \%), \mathrm{pH}$ 7.1. Strains of $\mathrm{S}$. lactis were grown in the same medium with the addition of $0.5 \%$ $\mathrm{Na}_{2} \mathrm{CO}_{3}$, pH 6.8. The medium of Volkin and Astrachan (28) was used when labeling cells with ${ }^{32} \mathrm{PO}_{4}$.

DNA preparation. Both labeled and unlabeled DNA were extracted and purified by a modification of the Marmur procedure (20). This modification includes the use of phenol and Pronase to provide more effective removal of protein. Approximately 1.5 liters of exponential-phase cells were harvested, washed, and resuspended in ice-cold distilled water to an optical density at $600 \mathrm{~nm}\left(\mathrm{OD}_{600}\right)$ of approximately 100 units. Cells were incubated with lysozyme $(1 \mathrm{mg}$ per $\mathrm{ml}$ per $10 \mathrm{OD}$ units; Calbiochem) at $37 \mathrm{C}$ for $30 \mathrm{~min}$ and lysed by the addition of $25 \%$ sodium dodecyl sulfate (SDS) to a final concentration of $1 \%$ (D. R. Roop, W. S. Riggsby, and J. O. Mundt, submitted for publication). After an initial chloroform-isoamyl alcohol $(24: 1, \mathrm{vol} / \mathrm{vol})$ extraction as in the Marmur procedure, the aqueous phase was extracted twice with redistilled water-saturated phenol followed by another chloroform-isoamyl alcohol extraction. After this series of deproteinizations, ribonuclease (Calbiochem; heated at $100 \mathrm{C}$ for $10 \mathrm{~min}$ ) was added to a final concentration of $50 \mu \mathrm{g} / \mathrm{ml}$, and the mixture was incubated for $30 \mathrm{~min}$ at $37 \mathrm{C}$. Predigested Pronase (Calbiochem) was then added to a final concentration of $50 \mu \mathrm{g} / \mathrm{ml}$ and allowed to digest for $1 \mathrm{~h}$ at $37 \mathrm{C}$. Deproteinizations using chloroform were resumed after this step, and the Marmur procedure was followed thereafter. DNA samples to be used in reassociation reactions were dissolved in $0.12 \mathrm{M}$ phosphate buffer (PB, an equimolar mixture of

TABLE 2. Strains used and their $T_{m}$ values and $G+C$ content

\begin{tabular}{|c|c|c|c|c|}
\hline Organism & Strain & Source & $\underset{\text { value }}{\mathrm{T}_{m}}$ & $\begin{array}{c}\mathrm{G}+\mathrm{C} \\
(\mathrm{mol} \%)\end{array}$ \\
\hline \multirow[t]{4}{*}{ Streptococcus faecalis } & $\mathrm{H} 27_{\mathrm{a}}$ & Stock cultures & $85.2 \pm 0.1^{a}$ & $38.4 \pm 0.2^{a}$ \\
\hline & 59 & Stock cultures & 84.3 & 36.4 \\
\hline & 60 & Stock cultures & 84.5 & 36.8 \\
\hline & 283 & Stock cultures & 85.0 & 38.1 \\
\hline \multirow[t]{3}{*}{ S. faecium } & 4 & Stock cultures & $85.0 \pm 0.1^{a}$ & $38.1 \pm 0.3^{a}$ \\
\hline & 1 & Stock cultures & 84.8 & 37.6 \\
\hline & 41 & Stock cultures & 84.9 & 37.8 \\
\hline S. faecium subsp. casseliflavus & ATCC 25788 & Stock cultures & 85.5 & 39.3 \\
\hline \multirow[t]{4}{*}{$S$. lactis } & $\mathrm{A} 1$ & R. H. Deibel & $83.2 \pm 0.1^{a}$ & $33.8 \pm 0.1^{a}$ \\
\hline & 5 & & 84.0 & 35.6 \\
\hline & $\mathrm{C}_{2} \mathrm{~F}$ & P. R. Elliker & 83.5 & 34.4 \\
\hline & $\mathrm{rm}$ & W. W. Overcast & 83.8 & 35.1 \\
\hline \multirow{8}{*}{ Atypical strains } & 48 & Stock cultures & 86.5 & 41.7 \\
\hline & 66 & Stock cultures & 85.4 & 39.0 \\
\hline & 122 & Stock cultures & 84.1 & 35.9 \\
\hline & 157 & Stock cultures & 84.7 & 37.3 \\
\hline & 172 & Stock cultures & 84.3 & 36.4 \\
\hline & 208 & Stock cultures & 83.5 & 34.4 \\
\hline & 246 & Stock cultures & 83.7 & 34.9 \\
\hline & 442 & Stock cultures & 85.7 & 39.8 \\
\hline Escherichia coli & $\mathrm{K}-12$ & B. M. Kline & 90.4 & 51.2 \\
\hline
\end{tabular}

${ }^{a}$ Standard deviation calculated only for three or more determinations. 
$\mathrm{Na}_{2} \mathrm{HPO}_{4}$ and $\mathrm{NaH}_{2} \mathrm{PO}_{4}, \mathrm{pH}$ 6.8) and fragmented with a Raytheon model DF-101 magnetostrictive sonicator to an average single-strand molecular weight of approximately $3 \times 10^{5}$ determined by sedimentation velocity in 5 to $20 \%$ alkaline sucrose gradients. Labeled fragments were dissociated by heating $10 \mathrm{~min}$ at $100 \mathrm{C}$ and were further purified by chromatography on hydroxyapatite (HA) (Bio-Gel HT, Bio-Rad Laboratories) equilibrated with $0.12 \mathrm{M} \mathrm{PB}$ and held at 60 C. Material bound to HA under these conditions was discarded. This procedure decreases the "zero time" binding (label bound to HA immediately after the DNA has been dissociated) to about $0.5 \%$ (5).

The amount of labeled DNA nonspecifically binding to HA was determined in each set of experiments for each labeled DNA preparation. Labeled DNA $(0.33 \mu \mathrm{g}$ in $1.0 \mathrm{ml}$ of $0.12 \mathrm{M} \mathrm{PB}$ ) was dissociated by heating 10 min at $100 \mathrm{C}$ and immediately chromatographed on $\mathrm{HA}$ at $60 \mathrm{C}$. Nonspecific binding values were less than $1 \%$ of the total counts per minute recovered from HA, and reassociation values were corrected for these amounts. The addition of SDS $(0.4 \%)$ to the PB in the thermal-stability experiments prevented nonspecific binding of DNA to HA and resulted in a reduction of nonspecific binding to $0.5 \%$. The specific activity of the ${ }^{32} \mathrm{P}$-labeled DNA was $1.0 \times 10^{4}$ to $2.0 \times 10^{4}$ counts per min per $\mu \mathrm{g}$.

DNA-DNA reassociation reactions. Reaction mixtures contained $0.33 \mu \mathrm{g}\left(0.008 \mathrm{OD}_{260}\right.$ units $)$ of ${ }^{32}$ P-labeled DNA and $166 \mu \mathrm{g}\left(4.0 \mathrm{OD}_{260}\right.$ units) of unlabeled DNA in $1.0 \mathrm{ml}$ of $0.12 \mathrm{M} \mathrm{PB}$. Mixtures were placed in sealed vials, dissociated by heating at $100 \mathrm{C}$ for $10 \mathrm{~min}$, and incubated immediately at 60 or $70 \mathrm{C}$ for $20 \mathrm{~h}$. These conditions permit at least $80 \%$ reassociation of the unlabeled fragments with each other or with labeled fragments while limiting reassociation of labeled fragments with one another to a few percent. The amount of reassociation of labeled DNA was found to be 2 to $3 \%$ of the total counts per minute recovered from $\mathrm{HA}$, determined in each set of experiments for each labeled DNA preparation by incubating $0.33 \mu \mathrm{g}$ of ${ }^{32}$ P-labeled DNA in $1.0 \mathrm{ml}$ of $0.12 \mathrm{M} \mathrm{PB}$ for $20 \mathrm{~h}$ after dissociation. Reassociation values were corrected for this background. After $20 \mathrm{~h}$ of incubation, vials were rapidly chilled in an ice-water bath and stored at $-20 \mathrm{C}$ until chromatographed on HA.

Reaction mixtures for thermal stability studies were as described above except for the presence of $0.005 \mathrm{M}$ ethylenediaminetetraacetic acid (EDTA) in the PB. EDTA was added to the PB to chelate any $\mathrm{Mg}^{2+}$ and therefore prevent deoxyribonuclease activity; however, there was no apparent difference in reassociation values for reactions performed in the presence of EDTA.

Separation of single- and double-stranded DNA on HA. HA containing $0.28 \mathrm{~g}$ (dry wt) $/ \mathrm{ml}$ was diluted with $0.001 \mathrm{M} P \mathrm{~PB}$ to a concentration that was three times that required to bind all the DNA contained in the reaction mixture (approximately $60 \mathrm{mg}$ (dry $\mathrm{wt}) / \mathrm{ml}$ ). The HA solution was boiled for $20 \mathrm{~min}$ before being used to reduce nonspecific adsorption of single-stranded DNA (4). The "batch" procedure of Brenner et al. (5), which permits simultaneous chromatography of 10 samples, was used. A $10-\mathrm{ml}$ amount of the boiled HA solution was placed in polypropylene centrifuge tubes $(40-\mathrm{ml}$ capacity). The tubes were placed in a Sorvall centrifuge, maintained at $70 \mathrm{C}$ in an incubator, and sedimented at $3,000 \mathrm{rpm}$ for $3 \mathrm{~min}$. The supernatants were discarded, and the HA was equilibrated with $0.12 \mathrm{M}$ PB by being washed three times with $15-\mathrm{ml}$ portions of this buffer. After discarding the third $\mathrm{PB}$ wash, the centrifuge tubes were placed in a 60 or $70 \mathrm{C}$ water bath. The frozen reaction mixtures were thawed and diluted with $14 \mathrm{ml}$ of prewarmed 60 or $70 \mathrm{C} 0.12 \mathrm{M} \mathrm{PB}$, added to the tubes, and mixed thoroughly with the HA. After allowing $20 \mathrm{~min}$ for equilibration, the tubes were rapidly transferred to the centrifuge and centrifuged as above. The supernatants were poured directly into counting vials. To elute the remaining single-stranded DNA, the tubes were replaced in the hot water bath and washed four more times with $15-\mathrm{ml}$ portions of $0.12 \mathrm{M} \mathrm{PB}$, allowing $5 \mathrm{~min}$ for equilibration of temperature. Double-stranded DNA was eluted by being washed four times with $15-\mathrm{ml}$ portions of $0.4 \mathrm{M}$ PB. To recover all reassociated material bound to the $\mathrm{HA}$, the $\mathrm{HA}$ was dissolved in $5 \mathrm{~N} \mathrm{HCl}(15 \mathrm{ml}$, final volume) and placed in a counting vial. Although the last step was routinely included, its use is questionable since few counts above background were recovered from the dissolved HA, and its omission would permit the recy cling of $\mathrm{HA}$.

The following procedure was used in determining the thermal stability of reassociated DNA fragments. For this set of experiments, $0.12 \mathrm{M} \mathrm{PB}$ containing $0.4 \% \mathrm{SDS}$ and $0.005 \mathrm{M}$ EDTA was used to elute single-stranded DNA from HA. Reaction mixtures were added to polypropylene tubes containing HA equilibrated with $0.12 \mathrm{M}$ PB containing $0.4 \%$ SDS and $0.005 \mathrm{M}$ EDTA. Tubes were placed in a water bath and washed five times as described with $15-\mathrm{ml}$ portions of $0.12 \mathrm{M} \mathrm{PB}$ and $0.4 \% \mathrm{SDS}$ at 60 or $70 \mathrm{C}$. The temperature of the water bath was then increased in increments of $2.5 \mathrm{C}$ to $90 \mathrm{C}$ and then raised to 95 and finally to $100 \mathrm{C}$. The $\mathrm{HA}$ was washed with one $15-\mathrm{ml}$ portion of $0.12 \mathrm{M} \mathrm{PB}$ and $0.4 \%$ SDS at each temperature, allowing $20 \mathrm{~min}$ for temperature equilibration. An additional wash using $0.4 \mathrm{M} \mathrm{PB}$ was performed at $100 \mathrm{C}$. The HA was finally dissolved in 5 $\mathrm{N} \mathrm{HCl}$ (15 ml, final volume) and placed in a counting vial.

Determination of $T_{m}$ and guanine plus cytosine $(\mathrm{G}+\mathrm{C})$ content of DNA. The median thermal dissociation temperature $\left(T_{m}\right)$ of each DNA sample was determined as described by Marmur (21). The equation of DeLey (14), \%G+C $=2.44\left(T_{m}-69.4\right)$, was used to calculate the $\mathrm{G}+\mathrm{C}$ content of each sample.

Determination of reassociation kinetics. Fragmented DNA samples at a concentration of $2.5 \mathrm{OD}$ units $/ \mathrm{ml}(104 \mu \mathrm{g})$ in $0.12 \mathrm{M} \mathrm{PB}$ were placed in ground-glass-stoppered cuvettes. Dissociation of the DNA was accomplished by heating the samples in the cuvettes at $100 \mathrm{C}$ for $10 \mathrm{~min}$. The samples were transferred immediately to a $60 \mathrm{C}$ chamber of a Beckman Acta III spectrophotometer. The absorbance of each sample was recorded at $2.5-\mathrm{min}$ intervals at $260 \mathrm{~nm}$ for a total of $40 \mathrm{~h}$. The temperature was measured by a platinum probe fixed in a sealed cuvette filled with mineral oil and recorded at the 
same intervals. Reassociation data were interpreted according to the method of Britten and Kohne (7).

Assay of radioactivity. Eluates from HA chromatography and dissolved HA were placed directly into counting vials and assayed by Cerenkov counting (8) in a Packard liquid scintillation counter.

\section{RESULTS}

$T_{m}$ analysis and $\mathrm{G}+\mathrm{C}$ content of DNA. A mean $T_{m}$ value of $84.8+0.4$ (mean $\% \mathrm{G}+\mathrm{C}=$ $37.4 \pm 1.0$ ) was obtained for the strains of $S$. faecalis and $84.9 \pm 0.1(\% \mathrm{G}+\mathrm{C}=37.8 \pm 0.3)$ for the strains of $S$. faecium (Table 2). These values are in agreement with those previously reported for these organisms $(11,22)$. The mean $T_{m}$ for all strains of $S$. lactis was $83.6 \pm 0.4(\% \mathrm{G}+\mathrm{C}=$ $34.7 \pm 0.8)$; this value compares favorably with that of 83.9 reported by Knittel et al. (18). $S$. faecium subsp. casseliflavus ATCC 25788 was found to have a $T_{m}$ of $85.5(\% \mathrm{G}+\mathrm{C}=39.3)$. The $T_{m}$ values obtained for atypical strains varied over a large range. $T_{m}$ determinations were made on $E$. coli $\mathrm{K}-12$ for control purposes. An average value of 90.4 was obtained as compared with 90.5 reported by Marmur (21). The $\mathrm{G}+\mathrm{C}$ content for these DNA samples is also presented in Table 2 .

Reassociation kinetics. $C_{0} t$ is defined as the product of the nucleic acid concentration $\left(C_{0}\right)$ and the time $(t)$ of reassociation. This is conveniently calculated as the product of DNA concentration expressed in $\mathrm{OD}_{260}$ units and the time of incubation expressed in hours, divided by two $\left(C_{0} t=\mathrm{OD}_{260} \times \mathrm{h} / 2\right)(7,19)$. The $C_{0} t_{1 / 2}$ is the $C_{0} t$ value at which half of the DNA is reassociated. The kinetics of reassociation of the DNA from $S$. faecalis strains $\mathrm{H} 27_{\text {a }}$ and $60, S$. faecium strains 41 and 1 , and $S$. lactis strains $\mathrm{C}_{2} \mathrm{~F}$ and $\mathrm{Al}$ were studied (7) to select conditions for the hybridization studies. Figure 1 shows the reassociation kinetics of $\mathrm{C}_{2} \mathrm{~F}$ and 41 . The $C_{0} t_{1 / 2}$ values for these DNAs were 4.7 and 7.4 , respectively. The $C_{0} t_{1 / 2}$ values for the other strains fell within this range (curves not shown). On the basis of these kinetic values, a $C_{0} t$ of $40\left(4.0 \mathrm{OD}_{260}\right.$ units, 20-h incubation) was chosen to allow greater than $80 \%$ of the unlabeled DNA to reassociate.

DNA-DNA hybridization studies. The results of hybridization experiments carried out at 60 $\mathrm{C}$ are presented in Table 3 . Routinely, 80 to $90 \%$ reassociation was obtained in the homologous reactions. The degree of DNA duplex formation in intraspecific reactions ( $S$. faecalis $/ S$. faecalis, $S$. faecium $/ S$. faecium, and $S$. lactis/S. lactis) was greater than $80 \%$, with the exception of the reaction involving $\mathrm{rm} / \mathrm{Al}$.

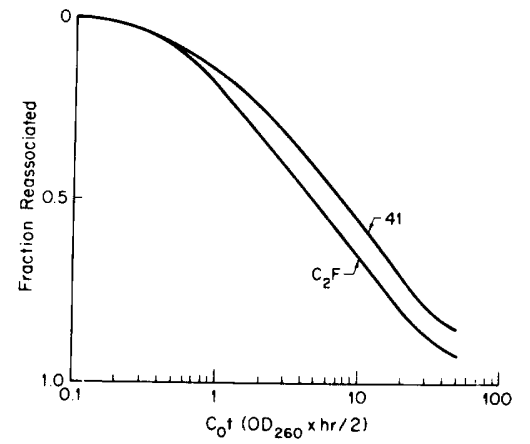

FIG. 1. Kinetics of reassociation of Streptococcus faecium 41 and S. lactis $C_{2} F D N A$ at $60 \mathrm{C}$.

Under these conditions, interspecific reassociations ( $S$. faecalis $/ S$. faecium and reciprocal reactions) showed a high degree of relatedness between these species. Low levels of binding, less than $10 \%$, were obtained in the interspecific reactions $(S$. lactis/S. faecalis, $S$. lactis $/ S$. faecium, and reciprocals). S. faecium subsp. casseliflavus ATCC 25788 exhibited low levels of binding in all reassociation reactions. Low levels of binding were also obtained in the reactions of the atypical strains with the three reference strains, with the exception of 157 , which showed moderate binding to $S$. faecium and $S$. faecalis.

In order to examine the duplex formation between reference strains from each species more closely, reciprocal reassociation reactions were carried out at 60 and $70 \mathrm{C}$ (Table 4). Incubation at $70 \mathrm{C}$ provides more stringent conditions for reassociation and precludes the duplex formation of all but highly complementary sequences. The thermal binding index (TBI), the ratio of binding at $70 \mathrm{C}$ to that at 60 $\mathrm{C}(4)$, can be useful in detecting the presence of closely related sequences in duplexes formed in interspecific reassociation reactions. The TBI approaches 1.0 in closely related organisms (6). The TBIs (Table 4) indicate a high degree of relatedness in duplexes formed between $S$. faecalis and $S$. faecium and the reciprocal, whereas little relatedness is exhibited in duplexes formed in reactions of $S$. lactis with $S$. faecalis and $S$. faecium and reciprocals.

Thermal stability studies. Thermal stability determinations were performed on the DNA duplexes formed in the reactions listed in Table 4. The thermal elution midpoint $\left(T_{m(e)}\right.$; that temperature at which $50 \%$ of the DNA bound to $\mathrm{HA}$ is eluted) values for duplexes formed in the homologous reactions were found to be approximately $3 \mathrm{C}$ higher than previously determined $T_{m}$ values for these strains (see Table 2). This was at least in part due to the 
TABLE 3. Extent of DNA-DNA reassociation at $60 \mathrm{C}^{a}$

\begin{tabular}{|c|c|c|c|c|}
\hline \multirow[b]{2}{*}{ Unlabeled source } & \multirow[b]{2}{*}{ Strain } & \multicolumn{3}{|c|}{ Labeled source } \\
\hline & & S. faecalis $\mathrm{H} 27_{\mathrm{a}}$ & S. faecium 4 & S. lactis Al \\
\hline \multirow[t]{4}{*}{ Streptococcus faecalis } & $\mathrm{H} 27_{\mathrm{a}}$ & 100 & 89 & 6 \\
\hline & 59 & 94 & 85 & 4 \\
\hline & 60 & 96 & 89 & 5 \\
\hline & 283 & 92 & 86 & 9 \\
\hline \multirow[t]{3}{*}{ S. faecium } & 4 & 81 & 100 & 2 \\
\hline & 1 & 89 & 99 & 7 \\
\hline & 41 & 76 & 86 & 5 \\
\hline S. faecium subsp. casseliflavus & ATCC 25788 & 11 & 9 & 3 \\
\hline \multirow[t]{4}{*}{ S. lactis } & A1 & 3 & 3 & 100 \\
\hline & 5 & 6 & 7 & 91 \\
\hline & $\mathrm{C}_{2} \mathrm{~F}$ & 1 & 3 & 83 \\
\hline & $\mathrm{rm}$ & 0 & 5 & 75 \\
\hline \multirow[t]{8}{*}{ Atypical strains } & 48 & 1 & 4 & 1 \\
\hline & 66 & 0 & 0 & 25 \\
\hline & 122 & 6 & 3 & 9 \\
\hline & 157 & 37 & 52 & 18 \\
\hline & 172 & 13 & 10 & 7 \\
\hline & 208 & 2 & 1 & 21 \\
\hline & 246 & 9 & 7 & 6 \\
\hline & 442 & 8 & 7 & 9 \\
\hline
\end{tabular}

${ }^{a}$ Expressed as percentage values normalized to the homologous value, designated as $100 \%$.

TABLE 4. Relative binding of DNA-DNA reassociation reactions at 60 and $70 C$

\begin{tabular}{|c|c|c|c|c|c|}
\hline Unlabeled source/labeled source & $\begin{array}{l}\text { Percent } \\
\text { relative } \\
\text { binding } \\
\text { at } 60 \mathrm{C}\end{array}$ & $\begin{array}{c}\Delta T_{m}(e) \\
\text { at } 60 C^{a}\end{array}$ & $\begin{array}{l}\text { Percent } \\
\text { relative } \\
\text { binding } \\
\text { at } 70 \mathrm{C}\end{array}$ & $\begin{array}{l}\Delta \mathrm{T}_{m}(e) \\
\text { at } 70 \mathrm{C}\end{array}$ & $\mathrm{TBI}^{b}$ \\
\hline $\begin{array}{l}\text { Streptococcus lactis A } 1 / S \text {. lactis A1 } \\
S . \text { faecalis } \mathrm{H} 27_{\mathrm{a}} / S \text {. lactis } \mathrm{A} 1 \\
\text { S. faecium } 4 / S \text {. lactis } \mathrm{A} 1 \\
\text { S. lactis } \mathrm{A} 1 / S . \text { faecalis } \mathrm{H} 27_{\mathrm{a}} \\
\text { S. faecalis } \mathrm{H} 27_{\mathrm{a}} / \text { S. faecalis } \mathrm{H} 27_{\mathrm{a}} \\
S . \text { faecium } 4 / S \text {. faecalis } \mathrm{H} 27_{\mathrm{a}} \\
\text { S. lactis } \mathrm{A} 1 / S \text {. faecium } 4 \\
\text { S. faecalis } \mathrm{H} 27_{\mathrm{a}} / \text { S. faecium } 4 \\
\text { S. faecium } 4 / S \text {. faecium } 4\end{array}$ & $\begin{array}{c}100 \\
4.0 \\
3.0 \\
7.0 \\
100 \\
81.0 \\
7.0 \\
92.0 \\
100\end{array}$ & $\begin{array}{l}0.0(14.7) \\
0.0(13.0) \\
1.0(17.3) \\
1.5 \\
3.0(19.9) \\
1.9\end{array}$ & $\begin{array}{c}100 \\
2.0 \\
1.0 \\
1.0 \\
100 \\
75.0 \\
4.0 \\
87.0 \\
100\end{array}$ & $\begin{array}{l}1.5 \\
0.8 \\
3.0 \\
\\
\\
0.0 \\
4.0 \\
1.5\end{array}$ & $\begin{array}{l}0.5 \\
0.33 \\
0.14 \\
\\
0.93 \\
0.57 \\
0.95\end{array}$ \\
\hline
\end{tabular}

$a$ The decrease in $\mathrm{T}_{m}(e)$ between heterologous reactions and the homologous reaction. The data in parentheses are for the first class of duplex molecules exhibited in biphasic curves (see Fig. 2).

$b$ Ratio of binding at $70 \mathrm{C}$ to that at $60 \mathrm{C}$.

fact that the $T_{m(e)}$ measures complete strand separation, whereas the $T_{m}$ determined spectrophotometrically measures the increase in optical density as strands separate (7). The decrease in $T_{m(e)}$ between heterologous reactions and homologous reaction $\left(\Delta T_{m(e)}\right)$ is useful in determining the divergence in related nucleotide sequences (6). It has been estimated that the presence of $1 \%$ unpaired bases within a reassociated polynucleotide fragment lowers its thermal stability by about $1 \mathrm{C}$ (3). Thermal elution curves of these duplexes are shown in Fig. 2.
In the case of duplexes formed between $S$. faecalis $\mathrm{H} 27_{\mathrm{a}} / S$. lactis $\mathrm{A} 1, \mathrm{~S}$. faecium $4 / S$. lactis $\mathrm{Al}$, and reciprocals at $60 \mathrm{C}$, the elution curves appeared to be biphasic. Therefore, we chose to regard them as representing the dissociation of two separate classes of duplex molecules, and a $T_{m(e)}$ was calculated for each class (Table 4). The first class has a large $\Delta T_{m(e)}$, indicating that there are 15 to $20 \%$ unpaired bases within these duplexes. The second class has a small $\Delta T_{m(e)}$, indicating less than $1 \%$ unpaired bases within the duplexes.

The total amount of duplex formation in 


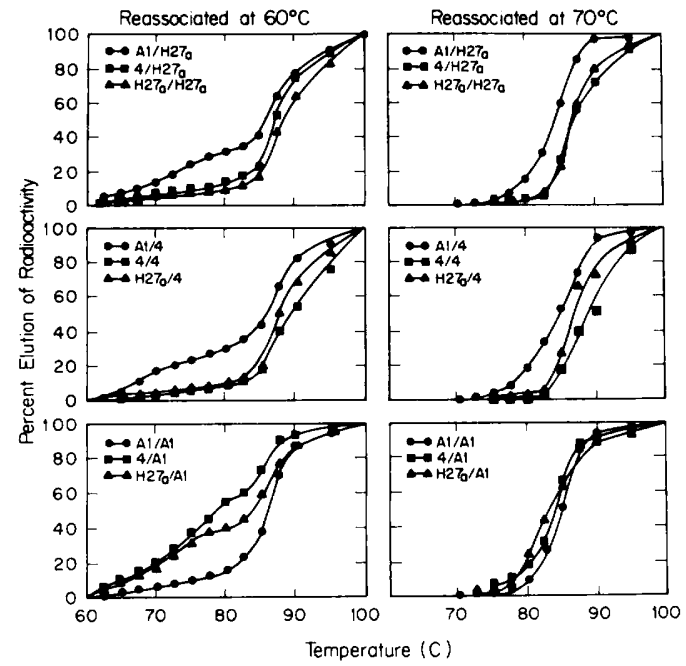

FIG. 2. Thermal elution curves of hybrid duplexes formed at 60 and $70 \mathrm{C}$ (see Table 4).

these reactions represents only 3 to $7 \%$ binding compared to the homologous reactions. At the more stringent temperature of $70 \mathrm{C}$, the low stability class is unable to reassociate as indicated by the elution curve and the decrease in relative percent bound. Duplexes formed between $S$. faecalis $\mathrm{H} 27_{\mathrm{a}}$, S. faecium 4 and reciprocal revealed a high degree of similarity with a small $\Delta T_{m(e)}$ at 60 and $70 \mathrm{C}$, indicating at most about $2 \%$ mismatch.

\section{DISCUSSION}

The results of this study indicate that differentiation between group $\mathrm{D}$ and group $\mathrm{N}$ streptococci can be easily made by using DNA-DNA hybridization. Less than $10 \%$ relatedness was exhibited in the interspecific reactions $(S$. lactis $/ S$. faecalis and $S$. lactis $/ S$. faecium). A high degree of similarity was shown between strains of $S$. faecalis and $S$. faecium as indicated by the amount of reassociation in interspecific reactions and the high TBI values (Table 4). From the $\Delta T_{m(e)}$ values (Table 4), it is estimated that there is less than $2 \%$ mismatch in duplexes formed between these species. It is, therefore, difficult to differentiate between them solely on the basis of DNA-DNA hybridization. On the basis of these results, numerous studies by others of the phenotypic expression of the organisms (reviewed by Deibel [12] and Hartman et al. [17]), and more recent studies $(9,11,26)$, we regard these organisms as members of separate but closely related taxa.

The results obtained with the atypical strains are particularly interesting in that these strains for the most part show no strong homology with any of the reference strains (Table 3 ). Only in the case of strain 157 was moderately high binding observed, indicating that this strain is significantly related to $S$. faecium and $S$. faecalis. Examination of the physiologic properties of this strain revealed that it possesses characteristics that were more typical of $S$. faecium than they were of $S$. faecalis or $S$. lactis. The atypical strains used in this preliminary study were chosen at random, and it is possible that strains screened on the basis of physiologic characteristics would show more homology. Further studies along these lines are in progress. However, on the basis of binding results of the other atypical strains, there appear to be strains which exhibit no appreciable binding to the reference strains used and which, therefore, must be excluded from these particular species. It is not possible to determine from the data whether these atypical strains comprise one or more new species. The $\mathrm{G}+\mathrm{C}$ content of the atypical strains used in this study and the results exhibited by these strains in hybridization studies do not indicate that they represent a homogeneous group of organisms, as was the finding of Raj and Colwell (26) for unclassified enterococci. Since the strains used in this study were isolated from plants and exhibit characteristics of group D and group $\mathrm{N}$ streptococci, they may represent a more diverse group than was used by these authors.

The reassociation data obtained in the reaction of $S$. faecium subsp. casseliflavus ATCC 25788 with the three reference strains indicate that this organism deserves at least the subspecific designation (Table 3); there was no apparent homology exhibited in any of the reactions. However, since only one strain was used, further studies using many strains are in progress to determine the homogeneity of this subspecies and its relationship to the species examined in this study. Amstein and Hartman (1) have recently suggested that $S$. faecium subsp. casseliflavus definitely deserves subspecific, if not specific, status on the basis of the examination of the fatty acid composition of enterococci by gas chromatography.

The differences observed in the percent reassociation in reciprocal reactions between $S$. faecalis $\mathrm{H} 27_{\mathrm{a}}$ and $S$. faecium 4 (Tables 3 and 4) at 60 and $70 \mathrm{C}$ suggest a difference in their genome sizes. The genome of strain $\mathrm{H} 27_{\mathrm{a}}$ appears to be 8 to $12 \%$ larger than that of strain 4. Differences in the genome size of these species of the same magnitude are also indicated from the $C_{0} t_{1 / 2}$ values. Strains within the same species also exhibit differences in 
genome size on the basis of $C_{0} t_{1 / 2}$ values. Brenner et al. (6) recently reported that strains within another recognized species ( $E$. coli) vary as much as $23 \%$ in genome size. This finding was based on reciprocal binding studies and spectrophotometrically determined reassociation rates. Gillis et al. (16) and Bak et al. (2) reported a similar observation for several other species on the basis of reassociation rate studies. Since a difference in genome size may complicate interpretation of the degree of relatedness between species (13), experiments designed to clarify this point are being incorporated in the studies in progress described above.

\section{ACKNOWLEDGMENTS}

This work was supported in part by American Cancer Society research grant P-586 and Public Health Service research grant FD 00111-08 from the Division of the Food and Drug Administration. D.R.R. is a Public Health Service predoctoral trainee (TO 1-AI 00435) of the National Institute of Allergy and Infectious Diseases, and W.S.R. is the recipient of a Public Health Service research career development award (5 KO4 CA 10692) from the National Cancer Institute.

We wish to thank T. C. Montie for a critical review of the manusript.

\section{REPRINT REQUESTS}

Address reprint requests to: Mr. Dennis R. Roop, Department of Microbiology, University of Tennessee, Knoxville, Tenn. 37916.

\section{LITERATURE CITED}

1. Amstein, F., and P. A. Hartman. 1973. Differentiation of some enterococci by gas chromatography. J. Bacteriol. 113:38-41.

2. Bak, A. L., C. Christiansen, and A. Stenderup. 1970. Bacterial genome sizes determined by DNA renaturation studies. J. Gen. Microbiol. 64:377380 .

3. Bautz, E. K. F., and F. A. Bautz. 1964. The influence of noncomplementary bases on the stability of ordered polynucleotides. Proc. Nat. Acad. Sci. U.S.A. 52:1476-1481.

4. Brenner, D. J., G. R. Fanning, K. E. Johnson, R. V. Citarella, and S. Falkow. 1969. Polynucleotide sequence relationships among members of the Enterobacteriaceae. J. Bacteriol. 98:637-650.

5. Brenner, D. J., G. R. Fanning, A. V. Rake, and K. E. Johnson. 1969. Batch procedure for thermal elution of DNA from hydroxyapatite. Anal. Biochem. 28:447-459.

6. Brenner, D. J., G. R. Fanning, F. J. Skerman, and S. Falkow. 1972. Polynucleotide sequence divergence among strains of Escherichia coli and closely related organisms. J. Bacteriol. 109:953965 .
7. Britten, R. J., and D. E. Kohne. 1966. Nucleotide sequence repetition in DNA. Carnegie Inst. Wash. Year B. 65:78-106.

8. Clausen, T. 1968. Measurement of ${ }^{32} \mathrm{P}$ activity in a liquid scintillation counter without use of scintillator. Anal. Biochem. 22:70-73.

9. Colman, G. 1968. The application of computers to the classification of streptococci. J. Gen. Microbiol. 50:149-158.

10. Colobert, L., and H. Blondeau. 1962. L'Espece Streptococcus faecalis. I. Etude de l'homogenate par la methode Adansonnienne. Ann. Inst. Pasteur (Paris) 103:345-362.

11. Colwell, R. R., M. Mandel, and H. Raj. 1967. The taxonomy of enterococci. Can. J. Microbiol. 13:917-919.

12. Deibel, R. H. 1964. The group D streptococci. Bacteriol. Rev. 28:330-366.

13. DeLey, J. 1969. Compositional nucleotide distribution and theoretical prediction of homology in bacterial DNA. J. Theor. Biol. 22:89-116.

14. DeLey, J. 1970. Re-examination of the association between melting point, buoyant density, and chemical base composition of deoxyribonucleic acid. J. Bacteriol. 101:738-754.

15. Facklum, R. R., and M. D. Moody. 1970. Presumptive identification of group D streptococci: the bile-esculin test. Appl. Microbiol. 20:245-250.

16. Gillis, M., J. DeLey, and M. DeCleene. 1970. The determination of molecular weight of bacterial genome DNA from renaturation rates. Eur. J. Biochem. 12:143-153.

17. Hartman, P. A., G. W. Reinbold, and D. A. Saraswat. 1966. Indicator organisms-a review. I. Taxonomy of the fecal streptococci. Int. J. Syst. Bacteriol. 16:197-221.

18. Knittel, M. D., C. H. Black, W. E. Sandine, and D. K. Fraser. 1968. Use of normal probability paper in determining thermal melting values of deoxyribonucleic acid. Can. J. Microbiol. 14:239-245.

19. Kohne, D. E. 1969. Isolation and characterization of bacterial ribosomal RNA cistrons. Carnegie Inst. Wash. Year B. 67:310-320.

20. Marmur, J. 1961. A procedure for the isolation of deoxyribonucleic acid from micro-organisms. J. Mol. Biol. 3:208-218.

21. Marmur, J., and P. Doty. 1962. Determination of the base composition of deoxyribonucleic acid from its thermal denaturation temperature. J. Mol. Biol. 5:109-118.

22. Mehta, B. M., and D. J. Hutchinson. 1970. Nucleic acid homology as a measure of genetic compatibility among streptococci and a strain of Diplococcus pneumoniae. Can. J. Microbiol. 16: 281-286.

23. Miller, A., and M. E. Morgan. 1968. Genetic homology and attempted transformation among certain lactic streptococci. J. Dairy Sci. 51:1-7.

24. Mundt, J. O., and W. F. Graham. 1968. Streptococcus faecium var. casseliflavus, nov. var. J. Bacteriol. 95: 2005-2009.

25. Mundt, J. O., and A. H. Johnson. 1959. Physiological properties of group D streptococci isolated from plants. Food Res. 24:21 8-223.

26. Raj, H., and R. R. Colwell. 1966. Taxonomy of 
enterococci by computer analysis. Can. J. Microbiol. 12:353-362.

27. Taylor, R. F., M. Ikawa, and W. Chesbro. 1971. Carotenoids in yellow-pigmented enterococci. J. Bacteriol. 105:676-678.
28. Volkin, E., and L. Astrachan. 1957. RNA metabolism in T2-infected Escherichia coli, p. 686-694. In W. D. McElroy and B. Glass (ed.), The chemical basis of heredity. The Johns Hopkins Press, Baltimore. 